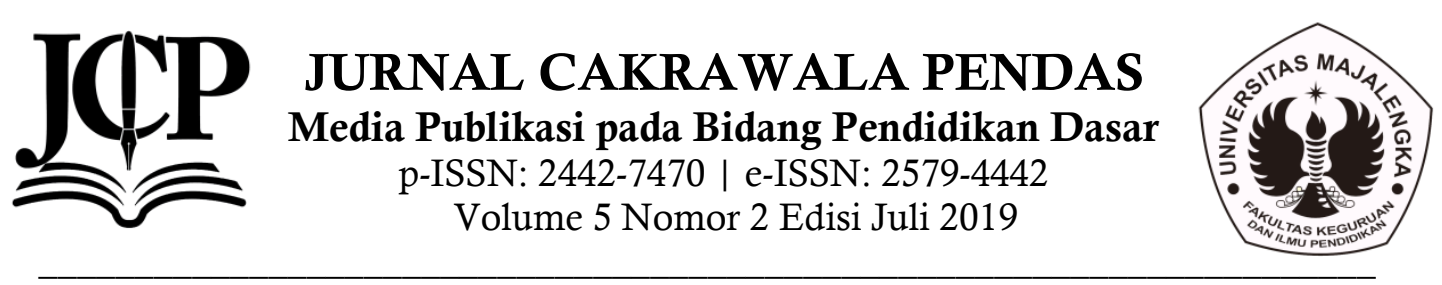

\title{
PENERAPAN MODEL COOPERATIVE LEARNING TIPE THINK PAIR SHARE (TPS) UNTUK MENINGKATKAN PEMAHAMAN KONSEP SISWA
}

\author{
Ari Yanto ${ }^{1}$ \\ ${ }^{1}$ Universitas Majalengka \\ ${ }^{1}$ ari.thea86@gmail.com
}

\begin{abstract}
Abstrak
Penelitian ini dilatarbelakangi masih rendahnya pemahaman konsep siswa, bertujuan untuk mengetahui peningkatan hasil belajar IPS siswa secara kognitif serta proses pembelajaran pada siswa kelas IV SDN Jagasari III melalui penerapan model cooperative learning tipe think pair share (TPS), Penelitian ini merupakan penelitian tindakan kelas dimana peneliti. Penelitian dilaksanakan dalam 3 siklus. Hasil penelitian menunjukkan bahwa penerapan model cooperative learning tipe think pair share (TPS) ditunjukkan dengan adanya peningkatan nilai dari sebelum pemberian tindakan hingga siklus III. Nilai rata-rata kelas yang diperoleh siswa sebelum pemberian tindakan adalah 58, sedangkan persentase siswa yang mencapai ketuntasan belajar adalah 30\%. Pada siklus I, nilai rata-rata kelas yang diperoleh siswa adalah 69 , sedangkan persentase jumlah siswa yang mencapai ketuntasan belajar adalah 50\%. Pada siklus II, nilai rata-rata kelas yang diperoleh siswa mencapai 83 sedangkan persentase jumlah siswa yang memperoleh nilai mencapai ketuntasan belajar adalah $90 \%$, dan pada siklus III, nilai rata-rata kelas yang diperoleh siswa adalah 90, sedangkan persentase jumlah siswa yang mencapai ketuntasan belajar adalah 95\%. Dari hasil penelitian tersebut dapat disimpulkan bahwa penerapan model cooperative learning tipe think pair share (TPS) dapat meningkatkan pemahaman konsep siswa kelas IV SDN Jagasari III.
\end{abstract}

Kata kunci: Pemahaman konsep siswa, model cooperative learning tipe think pair share (TPS) 


\section{Pendahuluan}

Pendidikan bagi siswa merupakan suatu proses untuk mendapatkan ilmu dan bekal di masa yang akan datang untuk meningkatkan kualitas sumber daya manusia, meraih cita-cita, mengembangkan potensi dirinya, melalui proses pembelajaran. Hal ini sesuai dengan Undang-Undang Republik Indonesia nomor 20 Tahun 2003 tentang Sistem Pendidikan Nasional bahwa:

Pendidikan adalah usaha sadar dan terencana untuk mewujudkan suasana belajar dan proses pembelajaran agar peserta didik secara aktif mengembangkan potensi dirinya untuk memiliki kekuatan spritual keagamaan , pengendalian diri, kepribadian, kecerdasan, akhlak mulia, serta keterampilan yang diperlukan dirinya, masyarakat, bangsa dan negara. Sanjaya, 2012:2).

Mata pelajaran IPS disusun secara sistematis dan terpadu dalam proses pembelajaran menuju kedewasaan dan keberhasilan dalam kehidupan masyarakat.

Pada jenjang SD / MI mata pelajaran IPS memuat materi geografi, sejarah, sosiologi dan ekonomi. Melalui mata pelajaran IPS peserta didik diarahkan untuk dapat menjadi warga negara yang baik, demokratis, dan bertanggung jawab serta warga dunia yang cinta damai. (Supriatna N, 2006: 2).

Menurut Bloom (dalam Susanto, 2013: 6), pemahaman konsep adalah seberapa besar siswa mampu menerima, menyerap, dan memahami pelajaran yang diberikan oleh guru kepada siswa, atau sejauh mana siswa dapat memahami serta mengerti apa yang ia baca, yang dilihat, yang dialami, dan mampu menggambarkan suatu pemikiran, gagasan, yang ia punya. Berdasarkan pendapat diatas bahwa pemahaman konsep merupakan proses untuk mengetahui sampai sejauh mana tingkat pemahaman konsep yang diperoleh siswa.

Berdasarkan hasil observasi di SDN Jagasari III Kecamatan Cikijing, Kabupaten Majalengka sebagai suatu lembaga formal di bidang pendidikan, maka didalamnya harus tercipta lingkungan pendidikan yang mampu menyediakan bermacam-macam kesempatan bagi siswa untuk aktif dalam proses pembelajaran, agar mereka mampu melakukan kegiatan belajar dengan efektif dan menyenangkan sehingga dapat menjadi sarana bagi siswa dalam menggali dan mengasah kemampuannya. Pada pembelajaran kelas IV biasanya guru hanya menggunakan metode ceramah sehingga kegiatan pembelajaran terpusat kepada guru. Selain itu cenderung membosankan karena siswa tidak terlibat aktif dalam proses pembelajaran, terlebih lagi pemahaman konsep siswa khususnya pada materi masalah-masalah sosial di lingkungan setempat masih banyak yang belum mencapai KKM, hal ini berdasarkan penelitian awal yang dilakukan pada siswa kelas IV yang terdiri dari 20 orang, adapun data awal hasil tes mengenai pemahaman konsep siswa yang memiliki kriteria ketuntasan minimal KKM 70, target pencapaian nilai hanya mencapai $30 \%$ (6 siswa) dan sisanya 70\% (14 siswa) belum mencapai target Kriteria Ketuntasan Minimal (KKM).

Menurut Shoimin (2014: 208) mengatakan bahwa Think Pair Share (TPS) adalah model pembelajaran cooperative yang memberi siswa waktu untuk berpikir dan merespon serta saling bantu sama lain. Model ini memperkenalkan ide "waktu berpikir atau waktu tunggu" yang menjadi faktor kuat dalam meningkatkan kemampuan siswa dalam merespon pertanyaan.

Menurut Shoimin (2014: 209), bahwa think pair share (TPS) mampu mengubah asumsi bahwa metode resitasi dan diskusi perlu diselenggarakan dalam setting kelompok kelas secara keseluruhan. Think pair share memberikan kepada siswa waktu untuk berpikir dan merespon serta saling bantu satu sama lain.

Belajar adalah suatu kegiatan yang dilakukan seseorang untuk memperoleh pengetahuan dan keterampilan melalui proses latihan dan interaksi dalam lingkungannya dalam upaya melakukan perubahan dalam dirinya secara menyeluruh baik berupa pengalaman, sikap dan perilaku.

Purwanto (dalam Kosasih dan Sumarna, 2013: 10) mengatakan bahwa belajar berhubungan dengan perubahan tingkah 
laku seseorang terhadap situasi tertentu yang disebabkan oleh pengalaman yang berulang-ulang, di mana perubahan tingkah laku itu tidak dapat dijelaskan atau dasar kecenderungannya berupa respon bawaan, kematangan atau keadaan sesaat seseorang.

Menurut Wager (dalam Kosasih dan Sumarna, 2013: 21) berpendapat bahwa "Pembelajaran adalah serangkaian kegiatan yang dirancang untuk memungkinkan terjadinya proses belajar pada siswa. Pembelajaran merupakan bantuan yang diberikan pendidik agar dapat terjadi proses perolehan ilmu dan pengetahuan, penguasaan kamahiran dan tabiat, serta pembentukan sikap dan kepercayaan pada siswa.

Hamdani (2011: 30), pembelajaran cooperative ini merupakan salah satu bentuk pembelajaran yang berdasarkan paham kontruktivis. Dalam pembelajaran cooperative diterapkan strategi belajar dengan sejumlah siswa sebagai anggota kelompok kecil yang tingkat kemampuannya berbeda.

Menurut Sapriya (2011: 21), IPS merupakan suatu program pendidikan dan bukan sub disiplin ilmu tersendiri, sehingga tidak akan ditemukan baik dalam nomenklatur filsafat ilmu, disiplin ilmuilmu sosial, maupun ilmu pendidikan. Dengan kata lain IPS mengikuti cara pandang yang bersifat terpadu dari jumlah mata pelajaran seperti geografi, ekonomi, ilmu politik, ilmu hukum, sejarah, antropologi, psikologi dan sebagainya.

Menurut Djahiri (dalam Susanto, 2013: 137-138), IPS adalah harapan untuk mampu membina suatu masyarakat yang baik dimana para anggotanya benar-benar berkembang sebagai insan sosial yang rasional dan penuh tanggung jawab, sehingga oleh karenanya diciptakan nilainilai. Hakikat IPS di sekolah dasar memberikan pengetahuan dasar dan keterampilan sebagai media pelatihan bagi siswa sebagai warga negara sedini mungkin.

\section{Metode Penelitian}

Penelitian ini termasuk penelitian tindakan kelas (classroom action research) kolaborasi. Menurut (Wina Sanjaya, 2009: 13) PTK merupakan salah satu upaya yang dapat dilakukan guru untuk meningkatkan kualitas peran dan tanggung jawab guru khususnya dalam pengelolaan pembelajaran.

Menurut Kemmis dan Taggart (Suwarsih Madya, 1994: 2), bahwa:

"Penelitian tindakan kelas adalah suatu bentuk penelitian refleksif diri kolektif yang dilakukan oleh peserta-pesertanya dalam situasi sosial untuk meningkatkan penalaran dan keadilan praktik pendidikan dan praktik sosail mereka, serta pemahaman terhadap praktik-paraktik itu terhadap situasi tempat dilakukan praktikpraktik tersebut".

Penelitian Tindakan Kelas adalah suatu bentuk kajian yang bersifat reflektif, yang dilakukan oleh peleku tindakan untuk meningkatkan kemantapan rasional dari tindakan dalam melaksanakan tugas dan memperdalam pemahaman terhadap kondisi dalam pratik pembelajaran (Hopkins dalam Muslich, 2011: 8). Penelitian Tindakan kelas merupakan suatu pencermatan terhadap kegiatan yang sengaja dimunculkan, dan terjadi dalam sebuah kelas (Zainal Aqib, 2006:13).

Menurut (Suhardjono, 2007: 58) mendefinisikan penelitian tindakan kelas adalah penelitian tindakan yang dilakukan di kelas dengan tujuan memperbaiki dan meningkatkan mutu pembelajaran. Menurut (Suharsimi Arikuntoro, 2008: 3), penelitian tindakan kelas merupakan suatu pencermatan terhadap kegiatan belajar berupa sebuah tindakan, yang sengaja dimunculkan dan terjadi dala sebuah kelas secara bersama.

Teknik dan alat pengumpul data yang digunakan dalam pe333nelitian tindakan kelas ini diantaranya adalah teknik tes dalam bentuk butir soal evaluasi dan teknik serta alat pada non tes sebagai berikut:

\subsection{Observasi}

Menurut Sugiyono (2013 : 156), "observasi merupakan suatu teknik untuk mengamati secara langsung terhadap kegiatan-kegiatan yang sedang berlangsung dengan menggunakan seluruh alat indera". Maka untuk memperoleh informasi dilakukan pengamatan yang termuat dalam lembar observasi guru dan siswa.

\subsection{Catatan Lapangan}

Catatan lapangan merupakan deskripsi keadaan di lapangan yang sesungguhnya yang diperoleh dari pengamatan dan 
analisa seluruh alat indera. Asrori (2016: 55) menyatakan bahwa "catatan lapangan tentunya diarahkan kepada segala sesuatu yang menarik perhatian guru dan dipandang penting dalam kaitannya dengan upaya perbaikan pembelajaran".

1.3. Dokumentasi

Dokumentasi diperlukan sebagai data pendukung penelitian. Bentuk dokumentasi berupa foto-foto kegiatan pembelajaran selama penelitian berlangsung.

\section{Hasil Penelitian}

Penelitian ini dilakukan sebanyak tiga siklus, setiap siklus terdiri dari dua tindakan. Pada setiap tindakan pembelajaran diterapkan dengan menggunakan model think pair share (TPS). Pembelajaran dalam setiap tindakan satu maupun dua dilakukan dengan kegiatan praktek dan setiap tindakannya dilakukan evaluasi pembelajaran melalui soal-soal uraian untuk mengetahui tingkat ketercapaian pemahaman konsep siswa tentang materi masalah-masalah sosial di lingkungan setempat.

\section{Siklus I}

\section{a. Kegiatan Pembelajaran I}

Kegiatan pembelajaran ini materinya adalah tentang jenis-jenis teknologi komunikasi masa lalu dan masa kini.

1. Perencanaan

a) Peneliti dan guru sebagai kolaborator menyiapkan materi yang akan disampaikan kepada siswa.

b) Menyiapkan rencana pelaksanaan pembelajaran (RPP).

c) Menyusun lembar observasi pembelajaran yang akan dilaksanakan. Lembar observasi ada 2 macam yaitu lembar observasi aktivitas siswa dan lembar observasi aktivitas guru. Lembar observasi ini digunakan untuk membandingkan aktivitas yang dilakukan siswa dan guru selama proses pembelajaran berlangsung dengan yang ada pada lembar observasi.

d) Menyusun dan menyiapkan LKS dan soal evaluasi untuk siswa. Soal akan diberikan pada setiap akhir siklus. Soal evaluasi disusun oleh peneliti dengan pertimbangan guru kelas dan penguji validitas soal.

e) Mempersiapkan media gambar sesuai dengan materi yang diajarkan.

f) Mempersiapkan kamera yang akan digunakan untuk mendokumentasikan aktivitas siswa selama proses pembelajaran berlangsung.

2. Pelaksanan Tindakan

Tahap pelaksanan tindakan ini antara lain :

a) Kegiatan Awal

1. Siswa berdoa bersama.

2. Siswa dikondisikan untuk siap melakukan pembelajaran. Melakukan apersepsi dengan guru bertanya kepada siswa "Melakukan apersepsi melalui tanya jawab seputar masalah pribadi. Beberapa siswa menanggapi pertanyaan guru.

b) Kegiatan Inti

Siswa mendengarkan materi yang disampaikan oleh guru sebagai pengantar pembelajaran. Siswa memperhatikan penjelasan dari guru Menujukkan gambar-gambar masalah pribadi. Siswa dipanggil secara bergantian untuk memasang/mengurutkan gambar di papan tulis mana yang termasuk.

\section{Refleksi Siklus I}

Refleksi siklus I dilakukan untuk membahas hal-hal yang menjadi hambatan pada siklus I. Kendala-kendala yang terjadi pada siklus I dipaparkan sebagai berikut:

a) Kualitas pewarnaan dan grafis media gambar yang disajikan oleh guru masih kurang bagus sehingga mengakibatkan siswa yang duduk dibagain belakang kesulitan untuk melihatnya.

Keaktifan siswa dalam pembelajaran masih belum optimal. Hal ini terlihat hanya sedikit siswa yang berani bertanya dan menjawab pertanyaan dari guru.

b) Guru belum maksimal menggunakan media ketika proses pembelajaran sehingga ada beberapa siswa belum memahami materi. 
c) Guru belum memberikan reward bagi siswa yang berprestasi

\section{Siklus II}

\section{a. Kegiatan Pembelajaran I}

Kegiatan pembelajaran ini materinya adalah tentang jenis-jenis teknologi transportasi masa lalu dan masa kini.

\section{Perencanaan}

Rencana tindakan pada siklus II ini hampir sama dengan perencanaan pada siklus I. Pelaksanaan siklus II akan dilakukan dengan memperhatikan hasil refleksi sebelumnya. Kendala-kendala yang dihadapi pada pelaksanaan siklus I diupayakan untuk diantisipasi. Berdasarkan refleksi pada silkus I maka pada tahap perencanaan tindakan siklus II, peneliti merancang tindakan yang akan dilaksanakan, meliputi :

a) Peneliti dan guru sebagai kolaborator menyiapkan materi yang akan disampaikan kepada siswa.

b) Menyiapkan rencana pelaksanaan pembelajaran (RPP).

c) Menyusun lembar observasi pembelajaran yang akan dilaksanakan. Lembar observasi ada 2 macam yaitu lembar observasi aktivitas siswa dan lembar observasi aktivitas guru. Lembar observasi ini digunakan untuk membandingkan aktivitas yang dilakukan siswa dan guru selama proses pembelajaran berlangsung dengan yang ada pada lembar observasi.

d) Menyusun dan menyiapkan LKS dan soal evaluasi untuk siswa. Soal akan diberikan pada setiap akhir siklus. Soal evaluasi disusun oleh peneliti dengan pertimbangan guru kelas dan penguji validitas soal.

e) Mempersiapkan kamera yang akan digunakan untuk mendokumentasikan b) Kegiatan Inti

Siswa mendengarkan penjelasan dari guru tentang materi pembelajaran dengan menampilkan gambar-gambar yang berkaitan dengan teknologi transportasi masa lalu dan masa kini beserta contohcontohnya dengan diselingi tanya jawab dengan siswa. Ketika melakukan tanya jawab, siswa diberikan kesempatan untuk menjawabnya. Setelah menjelaskan materi guru menyuruh siswa berdiri berpasangan di depan kelas bergantian. Kegiatan siswa di sini adalah menebak gambar. Seorang siswa diberi kartu pertanyaan yang berukuran $5 \times 10 \mathrm{~cm}$ untuk membacakan kata-kata yang tertulis didalamnya. Seorang siswa yang lain di beri beberapa gambar yang berukuran $10 \times 10 \mathrm{~cm}$ untuk menebak apa yang dimaksud dalam kartu pertanyaan dengan memilih gambar yang nanti pilihan gambarnya diperlihatkan pada teman lain.

Berdasarkan tabel di atas dapat dijabarkan sebagai berikut, dari 25 siswa sebanyak 22 siswa atau $88 \%$ sudah tuntas atau mencapai KKM. Sebanyak 3 siswa atau $12 \%$ belum tuntas atau belum mencapai KKM. Rata-rata kelas 79,6.

\section{Penerapan Pembelajaran dengan Menggunakan Model Pembelajaran Think Pair Share (TPS)}

Penerapan model pembelajaran think pair share (TPS) pada pembelajaran IPS pada materi masalah-masalah sosial dilingkungan setempat pada kelas IV SDN Jagasari III merupakan hal yang baru bagi siswa. Hal ini dikarenakan penerapan model pembelajaran think pair share (TPS) dalam pembelajarann IPS baru yang pertama kali bagi mereka. Para siswa merasa sangat antusias mengikuti pembelajaran. Suasana belajar dikelas menjadi sangat kondusif dan menyenangkan.

Ketika pelajaran dimulai para siswa sudah tampak siap dan sangat mengharapkan suasana pembelajaran yang berbeda dari sebelum-sebelumnya. Mereka lebih mudah menyerap materi pelajaran dengan media yang sudah disiapkan oleh guru, karena dengan menggunakan media yang baru siswa lihat, siswa lebih bersemangat lagi mengikuti pembelajaran dan suasana akan lebih menyenangkan.

Penerapan model pembelajaran kooperatif sendiri berarti tanpa kendala. Kendala yang peneliti amati siswa sulit terkontrol, tapi berkat perencanaan yang lebih matang akhirnya siswa dapat terkontrol dan bisa mengikuti pembelajaran dengan baik.

Pada siklus I kegiatan pembelajaran masih kurang seperti apa yang diharapkan. 
Hal ini disebabkan siswa masih merasa canggung dengan pembelajaran yang baru. Akibatnya siswa kurang begitu aktif dalam pembelajaran. Ketika pembelajaran berlangsung terlihat siswa yang tidak memperhatikan proses pembelajaran dan hanya diam saja, karena siswa pada saat pembelajaran jarang mengungkapkan pendapatnya, dan pada saat tanya jawab siswa masih merasa takut untuk mengungkapkan pendapatnya. Pada siklus II kekurangan-kekurangan pada siklus I telah diperbaiki, diantaranya guru melakukan pendekatan terhadap siswa yang tidak memperhatikan, dan guru pun mencari solusi agar siswa dapat mengikuti pembelajaran dengan baik. Karena penelitian belum mencapai maksimal peneliti melanjutnya penelitian ke siklus yang III, dan siklus ke III ini untuk memperbaiki pada siklus II dan pada siklus III pembelajaran lebih bermakna dan siswa lebih antusias pada saat guru menjelaskan materi yang akan dipelajari dan hampir semua siswa mengeluarkan pendapatnya dan bisa menjawab pertanyaan yang diajukan oleh guru maupun oleh teman sebayanya.

\section{Pemahaman Konsep Siswa dalam Pembelajaran IPS dengan Menggunakan Model Pembelajaran Think Pair Share (TPS)}

Sebelum diadakan tindakan pada penelitian ini hanya ada 6 orang siswa yang tuntas, sedangkan 14 orang siswa laiinya belum tuntas dan belum mencapai KKM. Karena pembelajaran di kelas menggunakan model dan media pembelajaran yang monoton, bahkan tanpa media sedikitpun selain buku. Dengan kondisi seperi itu sudah dapat dipastikan para siswa merasa jenuh dengan pembelajaran yang monoton seperti itu.

Kemudian setelah diadakan tindakan dengan menggunakan model pembelajaran think pair share (TPS) hasil belajar siswa meningkat. Pemahaman konsep ini meningkat diukur dengan tes dan nilai tes ini menemukan ketuntasan belajar siswa. Dalam penelitian ini telah tercapai ketuntasan belajar pada siklus III. Artinya penggunaan model pembelajaran think pair share (TPS) memberikan pengaruh positif terhadap pemahaman konsep siswa yang berdampak pada hasil belajar siswa secara umum dengan meningkatkan perolehan rata-rata kelas baik siklus I, II, dan III. Karena dengan menggunakan model pembelajaran think pair share (TPS) dan menggunakan media pada saat pembelajaran siswa bisa lebih aktif dalam pembelajaran dan hasil dari tes tersebut sangat memuaskan.

\section{Bagaimana Peningakatan Pemahaman Konsep Siswa Menggunakan Model Pembelajaran Think Pair Share (TPS)}

Berdasarkan hasil penelitian di ketahui bahwa dengan menggunakan model think pair share (TPS) dapat meningkatkan pemahaman konsep siswa. Pada pelaksanaan tindakan setiap siklusnya guru memberikan motivasi kepada siswa, dan guru juga menggunakan media yang belum pernah digunakan oleh guru kelasnya, dengan bantuan media tersebut siswa lebih antusias dalam pembelajaran dan siswa juga lebih aktif mengungkapkan pendapatnya tentang materi yang sedang diajarkan, dikarena pada proses pembelajaran sebelumnya guru hanya ceramah, dan pada saat peneliti mengajar menggunakan media untuk membantu proses pembelajaran. Proses pembelajaran di kelas berlangsung menyenangkan dan bermakna. Hal tersebut diindikasikan dari perolehan rata-rata siklus I (69), siklus II (83), dan siklus III (90). Peningkatan keberhasilan belajar siswa dari kondisi awal hingga siklus III dapat dilihat pada tabel dan grafik dibawah ini.

Tabel 1

Pembahasan Hasil Belajar Siswa

\begin{tabular}{llccc}
\hline No. & Siklus & $\begin{array}{c}\text { Jumlah } \\
\text { Siswa }\end{array}$ & $\begin{array}{c}\text { Jumlah } \\
\text { Siswa } \\
\text { yang } \\
\text { tuntas }\end{array}$ & $\%$ \\
\hline 1. & $\begin{array}{l}\text { Data } \\
\text { Awal }\end{array}$ & 20 & 6 & $30 \%$ \\
\hline 2. & $\begin{array}{l}\text { Siklus } \\
\text { I }\end{array}$ & 20 & 10 & $50 \%$ \\
\hline 3. & $\begin{array}{l}\text { Siklus } \\
\text { II }\end{array}$ & 20 & 18 & $90 \%$ \\
& & & \\
\hline
\end{tabular}




\begin{tabular}{lllll}
\hline 4. & Siklus & 20 & 19 & $95 \%$ \\
& III & & & \\
\hline
\end{tabular}

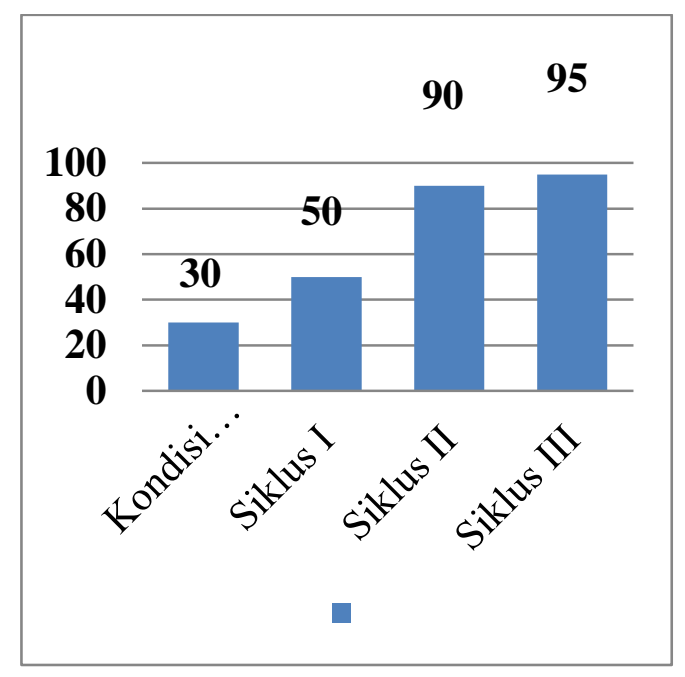

Gambar 1

Peningkatan Hasil Belajar Siswa

Berdasarkan grafik diatas hasil belajar siswa pada setiap siklus terus mengalami peningkatan. Setelah diberi perlakuan berupa model think pair share (TPS) paa data awal ketuntasan hanya $30 \%$. Disiklus I meningkat menjadi $50 \%$. Siklus II kembali meningkat menjadi $90 \%$, dan pada siklus terakhir yaitu siklus III meningkat lebih tinggi menjadi $95 \%$.

Berdasarkan hasil penelitian yang telah dilaksanakan tentang penerapan model pembelajaran think pair share (TPS) untuk meningkatkan pemahaman konsep siswa pada mata pelajaran IPS (PTK pada materi masalah-masalah sosial dilingkungan setempat di kelas IV SDN Jagasari III Kecamatan Cikijing Kabupaten Majalengka).

\section{Simpulan}

Proses pembelajaran dengan menerapkan model pembelajaran think pair share (TPS) dapat meningkatkan pemahaman konsep siswa pada mata pelajaran IPS. Para siswa merasa sangat antusias mengikuti pembelajaran. Suasana belajar dikelas menjadi sangat kondusif dan menyenangkan. Dapat dilihat dari selain mampu meningkatkan pemahaman konsep siswa pada materi ajar juga mampu memperbaiki aktifitas siswa selama proses pembelajaran, namun hal tersebut tidak akan berarti apabila kemampuan guru dalam mengondisikan siswa dan melakukan variasi meengajar tetap rendah, tetapi aktivitas guru pada saat penelitian dari siklus I sampai ke III mengalami perubahan di setiap siklusnya.

\section{Daftar Pustaka}

Majid, A. (2013). Strategi Pembelajaran. Bandung: PT Remaja Rosdakarya.

Hamdani. (2011). Strategi Belajar Mengajar. Bandung : Pustaka Setia.

Rusman. (2013). Model-Model Pembelajaran. Jakarta : PT Rajagrafindo Persada.

Sanjaya, W. (2009). Strategi Pembelajaran. Jakarta : Kencana.

Sapriya. (2011). Pendidikan IPS. Bandung : PT Remaja Rosdakarya.

Shoimin, A. (2014). Model Pembelajaran Inovatif dalam Kurikulum 2013. Yogyakarta : PT Ar-Ruzz Media.

Sugiono. (2013). Metode Penelitian Pendidikan. Bandung : Alfabeta.

Supriatna, N. (2006). Pendidikan IPS di Sd. Bandung : UPI Press.

Susanto, A. (2013). Teori Belajar dan Pembelajaran di Sekolah Dasar. Jakarta: Kencana. 